\title{
Incidence, Enumeration and Confirmation of Listeria and its Species in Ready-to-eat Street Vended Salads Sold at Various Outlets of Faisalabad City, Pakistan
}

\author{
Adnan Khaliq ${ }^{1}$ D , Harris Sajjad ${ }^{2}$, Muhammad Farhan Jahangir Chughtai ${ }^{1}$ (D), \\ Samreen Ahsan ${ }^{1} \mathbb{D}^{D}$, Atif Liaqat ${ }^{1}{ }^{\mathbb{D}}$, Assam Bin Tahir ${ }^{4}$, Lilya Ponomareva ${ }^{3}$, \\ Elena Khryuchkina $^{3}$ D , Evgeny Ponomarev ${ }^{3}$ (D) Elena Lavrushina3 ${ }^{3}$, \\ Nataliya Gubanova ${ }^{3}$ (D) Lidiia Kozlovskikh³ ${ }^{3}$, Dmitry Baydan ${ }^{3}$ (D) \\ and Mohammad Ali Shariati ${ }^{3 *}$ (D) \\ ${ }^{1}$ Department of Food Science and Technology, Khwaja Fareed University of Engineering and Information \\ Technology, Rahim Yar Khan, Pakistan. \\ ${ }^{2}$ Punjab Food Authority, Lahore, Pakistan. \\ ${ }^{3}$ K.G. Razumovsky Moscow State University of technologies and management (the First Cossack University), \\ Moscow, Russian Federation, Russia. \\ ${ }^{4}$ University Institute of Diet and Nutritional Sciences, Faculty of Allied Health Sciences, The University of \\ Lahore, Lahore, Pakistan.
}

\begin{abstract}
The desire for a healthy lifestyle and faster mode of preparation has supported the consumption of ready to eat fresh salad. Street vended salads are recognized as a source of pathogenic transamination in different parts of the world. The present study was designed to evaluate the safety status of fresh vegetable and Russian salads being sold at various food outlets of Faisalabad. Samples of freshly prepared salads were collected from representative selected different areas of Faisalabad city divided into four different zones (zone 1, zone 2, zone 3 and zone 4). Prevalence and enumeration of Listeria was done through microbial testing via the spread plate method. Among samples of vegetable salad, the highest prevalence of Listeria was found in the zone 2 (75\%) whereas Russian salad samples from zones 1 and 3 exhibited $62 \%$ prevalence, the highest among all 4 zones of study. On the whole, the lowest prevalence of Listeria was found in zone 4 ( $50 \%$ vegetable salad and $58 \%$ Russian salad). Biochemical conformation of Listeria done through different tests for the identification of various Listeria species, exhibited that Listeria monocytogenes and Listeria innocua were highly prevalent in samples from zones 1 and 3 respectively. The results will help to improve safety concerns associated with street vended foods
\end{abstract}

Keywords: Listeria, ready-to-eat, vended salads

*Correspondence: shariatymohammadali@gmail.com

(Received: July 03, 2021; accepted: August 04, 2021)

Citation: Khaliq A, Sajjad H, Chughtai MFJ, et al. Incidence, Enumeration and Confirmation of Listeria and its Species in Readyto-eat Street Vended Salads Sold at Various Outlets of Faisalabad City, Pakistan. J Pure Appl Microbiol. 2021;15(3):1625-1633. doi: 10.22207/JPAM.15.3.59

(C) The Author(s) 2021. Open Access. This article is distributed under the terms of the Creative Commons Attribution 4.0 International License which permits unrestricted use, sharing, distribution, and reproduction in any medium, provided you give appropriate credit to the original author(s) and the source, provide a link to the Creative Commons license, and indicate if changes were made. 


\section{INTRODUCTION}

Pathogenic microorganisms significantly exist in street vended foods and cause foodborne illnesses in all parts of world. Food borne illnesses not only effects consumer health also results in negative economic impacts, loss of customers, product recall and potential compensation costs $^{1}$. Contaminated foodstuff is the main cause oftwenty to thirty per cent spreading of Listeria infection that causes ninety-five percent cases of food poisoning ${ }^{2}$. Every year, almost one third population is distressed with foodborne infections in industrialized countries whereas the problem is worse in developing countries due to poverty, overcrowding, inadequate sanitary conditions and poor general hygiene ${ }^{3}$.

Listeria is a Gram-positive, bacillus, nonspore forming, ubiquitous, motile, facultative anaerobe and one of the most environmental pathogenic microflora of food ${ }^{4}$. Listeria can easily deteriorate the raw ready-to-eat foods because of its high salt tolerance and ability to thrive at low preservation temperatures. Listeria increases the rate of death up to $25-30 \%$ just because of hygienically poor environment and inadequate management of food processing ${ }^{5}$. Due to consumption of contaminated and unhygienic foods nearly 76 million infections, 325,000 hospitalizations and 5000 deaths are caused annually in United States of America ${ }^{24}$.

Rapid change in the socioeconomic status and changing life style have greatly increased the consumption of street vended foods $s^{6}$. Control of safety of ready to eat street vended foods is difficult and much important because they have significant socioeconomic role in meeting food and nutritional requirements of consumers at affordable prices particularly to the lower and middle income people. As these food products are prepared by small street vendors, cheaper rates of these foods attract the low earners. Ready to eat street vended foods constitutes the primary source of meals for many low and middle income people ${ }^{7}$. Salad, a mixture of vegetables and fruits, is an excellent source of dietary fiber, phytochemicals, antioxidants, minerals, vitamins and phenolic that help to cure many diseases and reduce the risk of developing type 2 diabetes ${ }^{10}$.
Salads are economical, convenient in preparation and have delicious taste but the hygiene and safety levels are big challenges for the food administrators. Freshly consumed produce got contaminated on farm or point of sale in market. Reported sources of contamination include soil, handling during pre and post-harvest handling, water and dust ${ }^{11}$. Manures used to promote the growth and cultivation of these produce harbor the large number of pathogenic microorganisms such as Salmonella, Mycobacterium, Listeria monocytogenes, Klebsiella and Clostridium perfringens ${ }^{9}$.Globally, about 325,000 people are hospitalized along with death of 5,000 children each year due to food borne illnesses ${ }^{14}$. Therefore, despite the freshness and nutritional benefits of fruits and vegetables, there have been an increase in incidence of food borne illnesses thus bacteriologically safe fruit and vegetable products are required to maximize the health benefits promised by their consumption ${ }^{8}$. Ingredients of salads are contaminated with soil, dust, irrigation water which are proved to be associated with pathogenicity of Listeria. Findings have reported the highest prevalence of Listeria monocytogenes in ready to eat salad samples followed by chicken products, beverages, egg based products, beef and seafood products ${ }^{13}$. In salads, Listeria has been reported to be isolated from fresh produce such as parsley, cucumber, cabbage, sprouts and water cress and resulted in morbidity and mortality in various parts of world ${ }^{12}$. The average shelf life of ready to eats ranges from 5-7 days and after opening of package product can be stored for two days at refrigeration conditions. Highly perishable, favorable $\mathrm{pH}$ (6.0-7.0), poor abidance to decontamination procedures and temperature abuse can increase the risk associated with these products ${ }^{27}$. In Pakistan street vendors to large restaurants are responsible for sale of ready to eat salads. Most common salads on retail sale include vegetable salad and Russian salad. Common vegetables used in vegetable salads include onion, cucumber, tomatoes, lettuce green pepper, radish, salt and spices commonly stored at ambient temperature during retail conditions.. While ingredients in Russian salads include fresh or boiled vegetables, mayonnaise, cream and 
spices stored at refrigeration conditions. This study provides the prevalence data of Listeria monocytogenes for Vegetable salad and Russian salad. The objectives of this study were to assess microbiological quality of freshly prepared street vended salads and to get information regarding the major sources of contamination.

\section{MATERIALS AND METHODS}

Sample of Vegetable and Russian salads were collected from four different zones of the Faisalabad city (Table 1). A total of 192 samples were picked during five weeks. Samples were kept in strict hygienic conditions in sterile zipper polythene bags, stored in an icebox under controlled temperature and brought to the Food Microbiology and Microbiology Laboratory, National Institute of Food Science and Technology, University of Agriculture, Faisalabad within an hour of its collection. Listeria selective agar was used for microbial analysis. Samples were homogenized in a peristaltic blender (Seward Europe) at $200 \mathrm{rpm}$ for 2 minutes. For this purpose, $25 \mathrm{~g}$ salad along with $25 \mathrm{~mL}$ of peptone water was taken in specialized stomacher bags ${ }^{15}$. Six serial dilutions were made by transferring $1 \mathrm{~mL}$ liquid sample from stomacher bag to the test tubes serial wise and transferred to the prepared Petri plates containing solidified Listeria Selective Agar Base (Oxoid). Spreading of the poured volume $(0.1 \mathrm{~mL})$ was done using a sterile spreader and plates were allowed to dry for 15 minutes (Fig. 1) ${ }^{16}$. After drying, incubation was done for 24 hours at $37^{\circ} \mathrm{C}$. After incubation, dark brown or blackish colored colonies grew over Listeria selective agar as depicted in Fig. 2. Colonies of Listeria were counted using the colony counter (galaxy 230-USA) and documented. Colony forming units per gram (CFU/g) were calculated using the following formula.

Table 1. Sampling plan for vegetable and Russian salads collection

\begin{tabular}{|c|c|c|c|c|c|}
\hline \multicolumn{3}{|c|}{ Zone 1 locations for collection of samples } & \multicolumn{3}{|c|}{ Zone 2 locations for collection of samples } \\
\hline No. & Vegetable salad & Russian Salad & No. & Vegetable salad & Russian Salad \\
\hline 1 & Yong Wala & $\begin{array}{l}\text { Ghulam } \\
\text { Muhammadabad } \\
\text { road }\end{array}$ & 1 & Canal road & Sargodha road \\
\hline 2 & Kotwali road & Tata bazar & 2 & $\begin{array}{l}\text { Abdullahpur } \\
\text { overpass }\end{array}$ & Millat road \\
\hline 3 & Narwala road & Sadar bazar & 3 & Tahir road & Fsd.-Sanghla hill road \\
\hline 4 & Jail road & Tariq road & 4 & Khaleeq road & Kashmir road \\
\hline 5 & Ganda nala road & Gulberg road & 5 & Noorpur road & Iqbal stadium \\
\hline 6 & Bakar mandi road & Makki road & 6 & Chibban road & Lhr.-Fsd. Shk. road \\
\hline 7 & Chiniot bazar & Kachari bazar & 7 & Shadman road & College road \\
\hline 8 & Oil depot road & Imam bargha road & 8 & Ittehad road & Wapda colony road \\
\hline \multicolumn{3}{|c|}{ Zone 3 locations for collection of samples } & \multicolumn{3}{|c|}{ Zone 4 locations for collection of samples } \\
\hline No. & Vegetable salad & Russian Salad & No. & Vegetable salad & Russian Salad \\
\hline 1 & Rasool park & Susan road & 1 & Liaqat abad & Samundari road \\
\hline 2 & Tufail shaheed road & Tezab mill road & 2 & Mulyanwala road & D-type colony road \\
\hline 3 & Younas road & Jaranwala road & 3 & Naimatabad road & Dijkot road \\
\hline 4 & Satyana road & D-ground & 4 & Sanni road & Samanabad road \\
\hline 5 & Maqbool road & Lower canal road & 5 & Main road & Railway road \\
\hline 6 & Usman road & Khawaja islam road & 6 & Saifabad road & Jhang road \\
\hline 7 & Allama Iqbal road & Illahi abad road & 7 & Talianwala road & AARI colony road \\
\hline 8 & Risalewala road & Warispura road & 8 & Bilal road & Fazal elahi road \\
\hline
\end{tabular}

Samples were collected in triplicate from each location. 
CFU/g = (Average No.of Colonies $x$ Dilution Number ) / (Dilution Factor $x$ Volume plated )

(Formula A)

DF $=$ (Volume of sample) / (Sample Volume + Diluent Volume)

\section{Biochemical Testing}

Two species of Listeria (Listeria monocytogenes and Listeria innocua) were identified and biochemically confirmed by through Gram staining, catalase, citrate, hydrogen sulfide, indole, methyl red and oxidase tests as described by the Laboratory Manual of Food Microbiology ${ }^{16}$. Statistical analysis was performed for to determine the significance of test results ${ }^{17}$ by using the completely randomized design with the help of Statistix 8.1 software.

\section{RESULTS AND DISCUSSION Vegetable Salad}

Prevalence of Listeria in street vended vegetable salad samples gathered from zone 1 ,
Table 2. Prevalence of Listeria in salad samples from different zones

\begin{tabular}{lcc}
\hline Locations & $\begin{array}{c}\text { Total prevalence } \\
\text { in vegetable salad }\end{array}$ & $\begin{array}{c}\text { Total prevalence } \\
\text { in Russian salad }\end{array}$ \\
\hline Zone 1 & $15 / 24(62 \%)$ & $15 / 24(62 \%)$ \\
Zone 2 & $18 / 24(75 \%)$ & $11 / 24(45 \%)$ \\
Zone 3 & $13 / 24(55 \%)$ & $15 / 24(62 \%)$ \\
Zone 4 & $12 / 24(50 \%)$ & $14 / 24(58 \%)$ \\
\hline
\end{tabular}

zone 2, zone 3 and zone 4 are shown in Table 2. Total of 24 samples of vegetable salad were collected separately from all four zones and the occurrence of Listeria was documented in percentage. Among 24 samples of vegetable salad 15 samples of vegetable salad illustrated positive results for the pathogen and the total prevalence of Listeria was recorded $62 \%$. The highest count of $1.59 \times 10^{8} \mathrm{CFU} / \mathrm{g}$ was recorded from Ganda Nala Road and the lowest count of $4.47 \times 10^{6} \mathrm{CFU} / \mathrm{g}$ was recorded from oil depot road (Table 3 ). Highest prevalence was found in the area of Yong wala and Narwala road whereas Listeria was not detected from the samples of Chiniot bazar. The following results are in accordance with the findings of
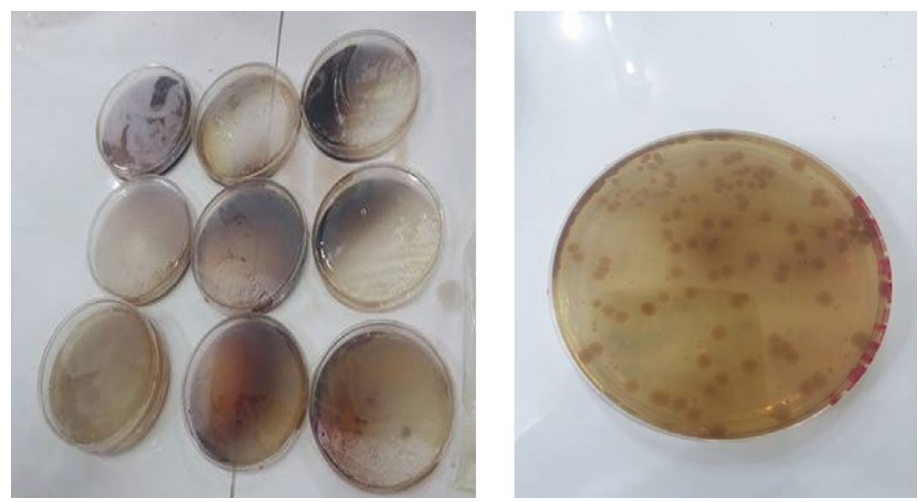

Fig. 1. Plates poured with isteria selective agar

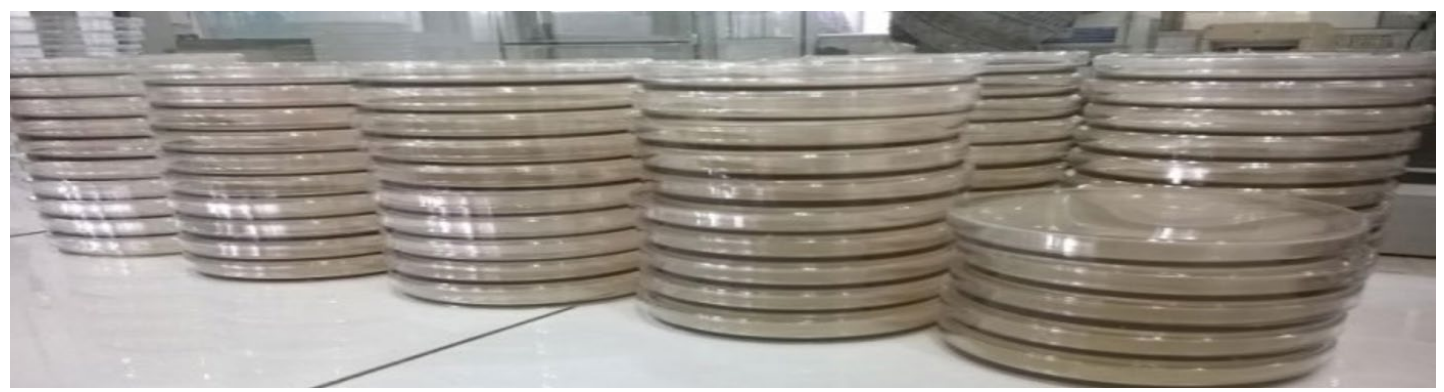

Fig. 2. Brown colored colonies of Listeria grown on Plates. 
Table 3. Prevalence and enumeration of Listeria in vegetable salad

\begin{tabular}{|c|c|c|c|c|}
\hline Zones & Location & $\begin{array}{c}\text { Satisfactory } \\
\text { Samples \% } \\
\left(<10^{1} \mathrm{CFU} / \mathrm{g}\right)\end{array}$ & $\begin{array}{l}\text { Un satisfactory } \\
\text { Samples \% } \\
\left(>10^{2} \mathrm{CFU} / \mathrm{g}\right)\end{array}$ & $\begin{array}{l}\text { Colony forming } \\
\text { unit (CFU/g) }\end{array}$ \\
\hline \multirow[t]{8}{*}{1} & Yong Wala & - & 100 & $1.30 \times 10^{7}$ \\
\hline & Kotwali road & 33 & 66 & $6.19 \times 10^{6}$ \\
\hline & Narwala road & - & 100 & $8.42 \times 10^{6}$ \\
\hline & Jail road & 33 & 66 & $1.12 \times 10^{8}$ \\
\hline & Ganda nala road & 33 & 66 & $1.59 \times 10^{8}$ \\
\hline & Bakar mandi road & 33 & 66 & $9.4 \times 10^{5}$ \\
\hline & Chiniot bazar & 100 & - & ND* \\
\hline & Oil depot road & 66 & 33 & $4.47 \times 10^{6}$ \\
\hline \multirow[t]{8}{*}{2} & Canal road & 66 & 33 & ND* \\
\hline & Abdullah pur overpass & 33 & 66 & $5.61 \times 10^{6}$ \\
\hline & Tahir road & - & 100 & $1.80 \times 10^{7}$ \\
\hline & Khaleeq road & 33 & 66 & $7.06 \times 10^{7}$ \\
\hline & Noorpur road & - & 100 & $3.86 \times 10^{6}$ \\
\hline & Chibban road & 33 & 66 & $8.73 \times 10^{7}$ \\
\hline & Shadman road & - & 100 & $1.40 \times 10^{8}$ \\
\hline & Ittehad road & 33 & 66 & $6.20 \times 10^{6}$ \\
\hline \multirow[t]{8}{*}{3} & Rasool park & 33 & 66 & $4.60 \times 10^{6}$ \\
\hline & Tufail shaheed road & 66 & 33 & $2.80 \times 10^{7}$ \\
\hline & Younas road & 33 & 66 & $6.39 \times 10^{6}$ \\
\hline & Satyana road & 66 & 33 & $4.86 \times 10^{5}$ \\
\hline & Maqbool road & - & 100 & $2.47 \times 10^{7}$ \\
\hline & Usman road & 33 & 66 & $1.06 \times 10^{8}$ \\
\hline & Allama iqbal road & 33 & 66 & $3.56 \times 10^{6}$ \\
\hline & Risalewala road & 33 & - & ND* \\
\hline \multirow[t]{8}{*}{4} & Liaqat abad & 66 & 33 & $6.73 \times 10^{6}$ \\
\hline & Mulyanwala road & 33 & 66 & $8.46 \times 10^{5}$ \\
\hline & Naimatabad road & 33 & 66 & $3.73 \times 10^{5}$ \\
\hline & Sanni road & 66 & 33 & $4.93 \times 10^{5}$ \\
\hline & Main road & 100 & - & ND* \\
\hline & Saifabad road & - & 100 & $2.99 \times 10^{7}$ \\
\hline & Talianwala road & 33 & 66 & $6.28 \times 10^{6}$ \\
\hline & Bilal road & 66 & 33 & $1 \times 10^{7}$ \\
\hline
\end{tabular}

Christson et $\mathrm{al}^{18}$ who reported the presence of Listeria monocytogenes in street vended salad which may cause health hazards.

In zone 2, prevalence of the pathogen was recorded as $75 \%$ in vegetable salad. Total 18 samples were positive for Listeria as shown in Table 3. Tahir road, Noorpur road and Shadman road have shown highest prevalence while no pathogen was detected in samples taken from Canal road with the non-significant difference $(P>$ $0.05)$. Enumeration results indicated highest count of $1.40 \times 10^{8}$ in samples from Shadman road while the lowest count of $3.86 \times 10^{6} \mathrm{CFU} / \mathrm{g}$ was recorded in samples collected from Noorpur road. The following results are in agreement with the study reported by El-Shenawy et a ${ }^{19}$ according to which Listeria is present everywhere in our environment and its various species like Listeria monocytogenes is responsible for many outbursts.

In zone 3 , overall $55 \%$ prevalence was observed in vegetable salads. None of the sample was found acceptable for the consumption. Highest count of $1.06 \times 10^{8} \mathrm{CFU} / \mathrm{g}$ was found in the area of Usman road whereas lowest count was shown in the area of Satyana road $\left(4.86 \times 10^{5} \mathrm{CFU} / \mathrm{g}\right)$ with no detection in the area of Risalewala road as presented in the Table 3. The following results are in accordance with the study of Lianou, \& Sofos ${ }^{20}$ who stated that inefficient methods of handling of street vended salads can support the growth of pathogenic micro 
Table 4. Prevalence and enumeration of Listeria in Russian salad

\begin{tabular}{|c|c|c|c|c|}
\hline Zones & Location & $\begin{array}{c}\text { Satisfactory } \\
\text { Samples \% } \\
\text { (<101 CFU/g) }\end{array}$ & $\begin{array}{c}\text { Un satisfactory } \\
\text { Samples \% } \\
\text { (>102 CFU/g) }\end{array}$ & $\begin{array}{l}\text { Colony forming } \\
\text { unit (CFU/g) }\end{array}$ \\
\hline \multirow[t]{8}{*}{1} & G.M Abad road & 66 & 33 & $3.86 \times 10^{5}$ \\
\hline & Tata bazar & 100 & - & ND* \\
\hline & Sadar bazar & 33 & 66 & $1.26 \times 10^{7}$ \\
\hline & Tariq road & 33 & 66 & $1.16 \times 10^{8}$ \\
\hline & Gulberg road & - & 100 & $2.62 \times 10^{6}$ \\
\hline & Makki road & 33 & 66 & $1.30 \times 10^{8}$ \\
\hline & Kachari bazar & 33 & 66 & $3.73 \times 10^{6}$ \\
\hline & Imam bargha road & 66 & 33 & $4.13 \times 10^{6}$ \\
\hline \multirow[t]{8}{*}{2} & Sargodha road & 100 & - & ND* \\
\hline & Millat road & - & 100 & $1.84 \times 10^{7}$ \\
\hline & Fsd.-Sanghla hill road & 33 & 66 & $7.66 \times 10^{5}$ \\
\hline & Kashmir road & 66 & 33 & $7.40 \times 10^{6}$ \\
\hline & lqbal stadium & 100 & - & ND* \\
\hline & Lhr Fsd Shk road & 66 & 33 & $5.13 \times 10^{7}$ \\
\hline & College road & - & 100 & $2.99 \times 10^{8}$ \\
\hline & Wapda colony road & 66 & 33 & $4.33 \times 10^{6}$ \\
\hline \multirow[t]{8}{*}{3} & Susan road & 100 & - & ND* \\
\hline & Tezab mill road & - & 100 & $2.63 \times 10^{6}$ \\
\hline & Jaranwala road & 33 & 66 & $8.87 \times 10^{6}$ \\
\hline & D-ground & 33 & 66 & $2.33 \times 10^{8}$ \\
\hline & Lower canal road & 33 & 66 & $4.44 \times 10^{7}$ \\
\hline & Khawaja islam road & 33 & 66 & $2 \times 10^{6}$ \\
\hline & Illahi abad road & 33 & 66 & $5.75 \times 10^{7}$ \\
\hline & Warispura road & 33 & 66 & $9.40 \times 10^{7}$ \\
\hline \multirow[t]{8}{*}{4} & Samundari road & - & 100 & $1.67 \times 10^{7}$ \\
\hline & D-type colony road & 100 & - & ND* \\
\hline & Dijkot road & 33 & 66 & $7.14 \times 10^{6}$ \\
\hline & Samanabad road & 33 & 66 & $7.01 \times 10^{6}$ \\
\hline & Railway road & 33 & 66 & $1.21 \times 10^{7}$ \\
\hline & Jhang road & 33 & 66 & $4.33 \times 10^{5}$ \\
\hline & AARI colony road & 66 & 33 & $3.33 \times 10^{5}$ \\
\hline & Fazal elahi road & 33 & 66 & $1.06 \times 10^{8}$ \\
\hline
\end{tabular}

flora in street vended foods. Most of the vendors openly store leftover food in an open place for the next day use ${ }^{21}$. Some of them also use stagnant water for washing which in result can cause serious health hazards.

In zone 4 , vegetable salads have shown the total prevalence of $50 \%$. Highest count was found in the area of Saifabad road that is $2.99 \times 10^{7}$ CFU/g whereas lowest count was observed in the samples taken from Naimatabad road $\left(3.73 \times 10^{5}\right.$ $\mathrm{CFU} / \mathrm{g})$. No pathogen was detected in the Main road samples. The results are in agreement with the work of Gelfand and colleague ${ }^{22}$ who describes the sources for the high prevalence of Listeria which may include the dusty unygenic premises and poor sanitary conditions.

\section{Russian Salad}

Result of the study (Table 2) presented the significant difference in samples of Russian salad in zone 1 and zone 3 with 62\% unsatisfactory results. None of the samples was found to be in the acceptable limits. In zone 1 , highest count of $1.30 \times 10^{8} \mathrm{CFU} / \mathrm{g}$ from Makki roadand the least count of $3.86 \times 10^{5} \mathrm{CFU} / \mathrm{g}$ were observed in the area of Ghulam Muhammadabad road whereas no Listeria was detected in the samples taken from 
Table 5. Biochemical testing of Listeria spp.

\begin{tabular}{cccc}
\hline Zones & Types of Salad & $\begin{array}{c}\text { Listeria } \\
\text { monocytogenes }\end{array}$ & $\begin{array}{c}\text { Listeria } \\
\text { innocua }\end{array}$ \\
\hline \multirow{2}{*}{ Zone 1 } & Vegetable Salad & $+(15 / 24)$ & $+(3 / 24)$ \\
& Russian Salad & $+(11 / 24)$ & $+(2 / 24)$ \\
Zone 2 & Vegetable Salad & $+(14 / 24)$ & $+(4 / 24)$ \\
& Russian Salad & $+(10 / 24)$ & $+(2 / 24)$ \\
Zone 3 & Vegetable Salad & $+(9 / 24)$ & $+(5 / 24)$ \\
& Russian Salad & $+(12 / 24)$ & $+(1 / 24)$ \\
Zone 4 & Vegetable Salad & $+(10 / 24)$ & $+(4 / 24)$ \\
& Russian Salad & $+(11 / 24)$ & $+(2 / 24)$ \\
\hline
\end{tabular}

Tata bazar with the overall count ranging from $105-10^{8} \mathrm{CFU} / \mathrm{g}$. These results are closely related to the previous work done ${ }^{23}$ which reports that fresh and mixed salads sold by road merchants harbor numerous pathogenic micro flora.

In zone 2, the percentage of total prevalence in Russian salad samples was $45 \%$ as documented in the Table 2. Enumeration of Listeria in Russian salad samples collected from zone 2 shown the significant results and the highest count was found in the area of College road with $2.99 \times 10^{8} \mathrm{CFU} / \mathrm{g}$ while the lowest count of Listeria was recorded in samples taken from Faisalabad-Sanghla hill road (Fsd.-Sanghla hill road) as $7.66 \times 10^{5} \mathrm{CFU} / \mathrm{g}$. No Listeria was detected in the samples gathered from the areas of Sargodha road and Iqbal Stadium as described in Table 4.These results are in accordance with the results of research in which shows that by adopting good hygiene practices like use of hygienic tops, aprons, utensils and good sanitary conditions can reduce the risk of Listeria by half.

Similar to zone 1 , percentage of total prevalence of Listeria in Russian salad samples was $62 \%$ with the highest count in the area of D-groundas $2.33 \times 10^{8} \mathrm{CFU} / \mathrm{g}$ while the least count was recorded in the samples taken from Khawaja Islam road $\left(2 \times 10^{6} \mathrm{CFU} / \mathrm{g}\right)$ and no Listeria was detected in the area of Susan road (Table 4).These results are in accordance with the work reported by Razzaq and colleagues ${ }^{21}$ that declared that most of the vendors openly store their leftover food in an open place for the next day use which is the significant reason of prevalence of Listeria. Results for the Russian salad samples collected from zone 4 depicted $58 \%$ total prevalence of Listeria with the highest count in the area of Fazal Elahi roadwith $1.06 \times 10^{8} \mathrm{CFU} / \mathrm{g}$ count while the least count was recorded in the samples taken from AARI colony road $\left(3.3 \times 10^{5} \mathrm{CFU} / \mathrm{g}\right)$. No Listeria was detected in the area of D-type colony road (Table 4). The results are in agreement with the work of Gelfand and coworkers ${ }^{23}$ that describes the sources for the high prevalence of Listeria. Similarly in another study conducted in Malaysia commercially available minimally processed vegetable salads were analyzed microbiologically and Listeria monocytogens and Listeria spp. were detected in $22.5 \%$ and $33.3 \%$ samples respectively ${ }^{26}$.

\section{Biochemical Testing}

Biochemical conformation for the identification of various Listeria species (resulted shown in Table 5) indicated that the percentage of Listeria monocytogenes in vegetable salad and Russian salad was $62 \%$ and $45 \%$ respectively in the samples collected from zone 1 , while the occurrence of Listeria innocua in the samples of vegetable salad and Russian salad was $16 \%$ and $8 \%$. In the zone 2, the prevalence of Listeria monocytogenes in vegetable and Russian salad samples was $58 \%$ and $41 \%$ while that of Listeria innocua was $16 \%$ and $8 \%$ in vegetable and Russian salad samples respectively. In zone 3 , the total percentage of Listeria monocytogenes in vegetable and Russian salad was $37 \%$ and $45 \%$, whereas the percentage of Listeria innocua was $16 \%$ and $12 \%$ respectively. Similarly, in the zone 4 , the occurrence of Listeria monocytogenes $41 \%$ and $45 \%$ while in case of Listeria innocua the prevalence was recorded as $16 \%$ and $8 \%$ in vegetable and Russian salad samples respectively. A study conducted in Brazil on 162 minimally processed vegetable salad samples sold locally also showed similar results containing Listeria monocytogenes, Salmonella and Escherichia coli at levels above (World Health Organization) WHO recommended limits ${ }^{25}$. In present study high Listeria count indicates increased consumer's exposure to microorganisms as it is assumed that the pathogen level were not reduced from post salad production to the utilization point because salads were served as ready to eat form and were stored at room temperature for sale. Possibility is that rework salad from last day was also mixed in new lot to utilize it risking the overall quality of product. Therefore holding temperature 
and Thermal processing have strong impact on microbiological safety. The quality and safety of vegetables used for ready to eat salad preparation also depend upon use of clean irrigation water and appropriate washing to remove residues of soil and organic fertilizers. Thus for the prevention of increased bacterial load application of good hygiene practices, effective control on storage condition, decontamination and selection of appropriate packaging material is necessary.

\section{CONCLUSION}

The study revealed that the microbiological quality of salads sold at various markets of Faisalabad were unwholesome for human consumption. On overall basis, Listeria monocytogenes was the most prevalent specie of Listeria that was found in most of the samples of salads collected from all zones. On the other hand, the prevalence of Listeria innocua was very low as compared to Listeria monocytogenes.

The contamination could be attributed to the productuion source of vegetables, use of contaminated water for washing, improper handling, use of dirty processing utensils, knives and trays, poor personal hygiene and improper storage conditions generally along environmental conditions and cross contamination from rotten vegetables in value chain Simple washing of vegetables before use can possibly reduce the risk of microbiological hazards. The need is to provide basic food hygiene training to food handlers and to create consumer awareness to consume properly processed food products. Further it is recommended that research should be carried out on salads to isolate bacterial pathogenic strains identified in present study and antimicobial susceptibility of identified bacteria.

\section{ACKNOWLEDGMENTS}

Authors gratefully acknowledge the Food Microbiology and Dairy Technology Laboratory, National Institute of Food Science and Technology, University of Agriculture, Faisalabad and Department of Food Science and Technology, Khwaja Fareed University of Engineering and Information Technology, Rahim Yar Khan, Pakistan for the provision of technical and scientific expertise during this study. .

\section{CONFLICT OF INTEREST}

The authors declare that there is no conflict of interest.

\section{AUTHORS' CONTRIBUTION}

All authors listed have made a substantial, direct and intellectual contribution to the work, and approved it for publication.

\section{FUNDING}

None.

\section{DATA AVAILABILITY}

All data set generated or analyzed during the study are included in the manuscript.

\section{ETHICS STATEMENT}

This research does not contain any studies with human participants or animals performed by any of the authors.

\section{REFERENCES}

1. Carrasco E, Perez-Rodriguez F, Valero A, Garcia-Gimeno RM, Zurera G. Risk assessment and management of Listeria monocytogenes in ready-to-eat lettuce salads. Compr Rev Food Sci Food Saf. 2010;9(5):498-512. doi: 10.1111/j.1541-4337.2010.00123.x

2. Thevenot D, Dernburg A, Vernozy-Rozand C. An updated review of Listeria monocytogenes in the pork meat industry and its products. J Appl Microbiol. 2006;101(1):7-17. doi: 10.1111/j.13652672.2006.02962.x

3. Hu X, Swiecicka I, Timmery S, Mahillon J. Sympatric soil communities of Bacillus cereus sensu lato: population structure and potential plasmid dynamics of pXO1-and pXO2-like elements. FEMS Microbiol Ecol. 2009;70(3):344-355. doi: 10.1111/j.15746941.2009.00771.x

4. Abebe E, Gugsa G, Ahmed M. Review on Major FoodBorne Zoonotic Bacterial Pathogens. J Trop Med. 2020;29;2020:4674235. doi: 10.1155/2020/4674235

5. Garode A, Waghode S. Bacteriological status of streetvended foods and public health significance: A Case Study of Buldana District, MS, India. ISCA J Biol Sci. 2012;1:69-71.

6. Aptrakhimov D, Rebezov M, Slavyanskiy A, et al. Composite flour pasta processing technology and its nutritive value. Journal of Natural Remedies. 2021;21(9):67-71.

7. FAO. Good hygienic practices in the preparation and sale of street food in Africa. FAO Corporate Document Repository. 2009.

8. Eni AO, Oluwawemitan IA, Solomon OU. Microbial quality of fruits and vegetables sold in Sango Ota, Nigeria. African J Food Sci. 2010;4:291-296.

9. Rahman F, Noor R. Prevalence of pathogenic bacteria in common salad vegetables of Dhaka Metropolis. 
Bangladesh J Botany. 2013;41(2):159-162. doi: 10.3329/bjb.v41i2.13442

10. Campos J, Gil J, Mourao J, Peixe L, Antunes P. Readyto-eat street-vended food as a potential vehicle of bacterial pathogens and antimicrobial resistance: an exploratory study in Porto region, Portugal. Int J Food Microbiol. 2015;206:1-6. doi: 10.1016/j. ijfoodmicro.2015.04.016

11. Jeddi MZ, Yunesian M, Gorji MEH, Noori N, Pourmand MR, Khaniki GRJ. Microbial evaluation of fresh, minimally-processed vegetables and bagged sprouts from chain supermarkets. J Health Popul Nutr. 2014;32(3):391-399.

12. Tonder IV, Lues JFR, Theron MM. The personal and general hygiene practices of food handlers in the delicatessen sections of retail outlets in South Africa. J Environ Health. 2007;70(4):33-38.

13. Jamali H, Chai LC, Thong KL. Detection and isolation of Listeria spp. and Listeria monocytogenes in readyto-eat foods with various selective culture media. Food Control. 2013;32(1):19-24. doi: 10.1016/j. foodcont.2012.11.033

14. Yousef $\mathrm{AE}$, Carlstrom C. Food microbiology: a laboratory manual, John Wiley \& Sons. 2003.

15. Uzeh RE, Alade FA, Bankole M. The microbial quality of pre-packed mixed vegetable salad in some retail outlets in Lagos, Nigeria. African Journal of Food Science. 2009;3(9):270-272.

16. Kiiyukia C. Laboratory manual of food microbiology for Ethiopian health and nutrition research institute. UNIDO project. 2003. (YA/ETH/03/436/11-52).1-197.

17. Montgomery DC. Design and Analysis of Experiments. $7^{\text {th }}$ Ed. John Wiley and Sons. Inc. Hoboken, NJ, USA. 2008;1-656.

18. Christison CA, Lindsay D, Von Holy A. Microbiological survey of ready-to-eat foods and associated preparation surfaces in retail delicatessens, Johannesburg, South
Africa. Food Control. 2008;19(7):727-733. doi: 10.1016/j.foodcont.2007.07.004

19. El-Shenawy M, El-Shenawy M, Manes J, Soriano JM. Listeria spp. in street-vended ready-to-eat foods. Interdiscip Perspect Infect Dis. 2011;2011:968031. doi: 10.1155/2011/968031

20. Lianou A, Sofos JN. A review of the incidence and transmission of Listeria monocytogenes in ready-toeat products in retail and food service environments. J Food Prot. 2007;70:2172-2198. doi: 10.4315/0362028x-70.9.2172

21. Razzaq R, Farzana K, Mahmood S, Murtaza G. Microbiological analysis of street vended vegetables in Multan City, Pakistan: A public health concern. Pakistan J Zool. 2014;46:1133-1138.

22. Gelfand MS. Treatment, prognosis, and prevention of Listeria monocytogenes infection. UpToDate. 2013;25:1-9.

23. Edelson BT, Unanue ER. Immunity to Listeria infection. Curr Opinion Immunol. 2000;12(4):425-431. doi: 10.1016/S0952-7915(00)00112-6

24. Mustafa M, Yoshida T, Waheed Z. Seafood poisoning, symptom, treatment, and prevention. BBJoMSA. 2018;2:64-69.

25. De Oliveira MA, De Souza VM, Bergamini AMM, De Martinis ECP. Microbiological quality of ready-to-eat minimally processed vegetables consumed in Brazil. Food Control. 2011;22(8):1400-1403. doi: 10.1016/j. foodcont.2011.02.020

26. Ponniah J, Robin T, Paie MS, et al. Listeria monocytogenes in raw salad vegetables sold at retail level in Malaysia. Food Control. 2010;21(5):774-778. doi: 10.1016/j.foodcont.2009.09.008

27. Arienzo A, Murgia L, Fraudentali I, Gallo V, Angelini $\mathrm{R}$, Antonini G. Microbiological quality of ready-toeat leafy green salads during shelf-life and homerefrigeration. Foods. 2020;9(10):1421. doi: 10.3390/ foods 9101421 